UDC 061.2:341.123.043

DOI: https://doi.org/10.18485/iipe_ria.2021.72.1182.3

Biblid 0543-3657, 72 (2021)

Vol. LXXII, No. 1182, pp. 47-65

Review article

\title{
NGOs AND THE UN SECURITY COUNCIL: BETWEEN INFORMAL REALITY AND POSSIBILITIES OF FORMAL INTERACTION
}

\author{
Jelica GORDANIĆ1
}

\begin{abstract}
Following the end of the Cold War, non-governmental organizations (NGOs) took the initiative in their interactions with the UN Security Council. Since then, mechanisms for informal consultations between NGOs and the Security Council have been established. Through informal consultations, NGOs have successfully influenced the decisions of the Security Council in the area of soft policy. It is critical to take appropriate measures in a timely manner when it comes to international peace and security. Mechanisms of informal access are not able to provide this request because they depend on the goodwill of the permanent members of the Security Council. The author examines possibilities for the establishment of formal interaction between the Security Council and NGOs. The author considers the UN Charter revision or granting international legal personality to NGOs as solutions for the establishment of formal interaction. Until one of these options happens, the paper considers that the Security Council and its permanent members must be more open towards NGOs and use NGOs' resources to improve their own reputation and increase transparency.

Keymords: NGOs, the Security Council, UN Charter revision, international legal personality, informal consultations, transparency, formal interaction, permanent members of the Security Council.
\end{abstract}

\section{INTRODUCTION}

The Security Council is a body primarily responsible for the maintenance of international peace and security within the UN system. Over the years, the UN

\footnotetext{
${ }^{1}$ Research Fellow, Institute of International Politics and Economics, Belgrade.

E-mail: jelica@diplomacy.bg.ac.rs
}

The paper presents findings of a study developed as a part of the research project "Serbia and challenges in international relations in 2021", financed by the Ministry of Education, Science, and Technological Development of the Republic of Serbia, and conducted by the Institute of International Politics and Economics, Belgrade. 
member states have noticed a few negative tendencies related to the functioning of the Security Council.

The Security Council has been criticized on multiple levels for being in a democratic deficit. The fact that the UN Charter gives permanent Security Council membership (the P-5) and the veto power of the permanent members, makes the P-5 more equal than the others. The Security Council has been criticized for being insufficiently representative of the broader membership of the UN. The remaining ten seats on the Council are elected for two-year terms, with five incomings and five outgoings each year. Legal theorists consider that it is unlikely that the Security Council, as an undemocratic body, "would operate democratically and reach democratic outcomes in its decision-making" and that it is "equally unlikely that such an undemocratic entity would make decisions that serve the interests of democracy" (Farrall 2009, 917-918).

The veto power of the permanent members, the frequent abuse of the veto, the lack of transparency, scandals and manipulations relating to peacekeeping operations have cast a shadow over its reputation. In the legal literature, the Security Council has been characterized as "a superpower organ with contrasting aspirations of the majority of the members of the UN" (Rath 2006, 61), "an oligarchic" and "an exclusive club" (Dimitrijević 2009, 11). It has been compared to "an international police officer who has centralized the application of international law" (Jovanović 2015, 61).

What could be a possible "cure" for the damaged reputation and the lack of transparency of the Security Council? Could it be an interaction with nongovernmental organizations (NGOs)? NGOs are very active participants in the international arena - in the area of international politics as well as international law. They have made significant contributions to the development of international law, human rights, environmental law, humanitarian law, etc. NGOs are often invited to take part in international affairs because they are seen as "representing civil society" and, as such, their participation is interpreted as legitimizing or democratizing the whole process (Martens 2003, 24). Nowadays, NGOs have the capacity to influence international organization policy and to intervene directly in choices traditionally reserved for individual sovereign states under international law. They exercise real power in the international community (Tarlock 1992, 65). Theorists consider that the inclusion of non-state actors might be a way to mitigate the democratic deficit in global governance, but the Security Council has been considered as a "hard case" for opening up to NGOs (Binder 2008, 2).

The paper investigates how interaction with NGOs can help increase transparency and repair the Security Council's tarnished reputation. What obstacles are NGOs faced with when it comes to interaction with the Security Council? Could these obstacles be overcome? To what extent is the Security Council open 
to interaction with NGOs? Are there some possibilities for formal interaction between NGOs and the Security Council in the future? These are some of the questions that require answers.

\section{NGOS INITIATIVES FOR INTERACTION WITH THE SECURITY COUNCIL}

As a response to a great increase in the Security Council activity in the postCold War era, the General Assembly has started negotiations on the reform of the Security Council. NGOs based in New York and Geneva decided to get involved. NGOs established the NGO Working Group on the Security Council in early 1995, with the aim of influencing the debate about the reform of the Security Council. The working group has organized two public meetings on reform topics as well as several private meetings with delegates and with the office of the General Assembly President to propose initiatives and gain support (Paul 2010).

Just two years later, it was clear that Security Council reform was a slow and never-ending process. The NGO Working Group had to change course. It began to organize a public dialogue between the Council members and the NGO community in 1996. The aim of these dialogues was the establishment of formal interaction between NGOs and the Security Council. The NGO Working Group approached Ambassador Juan Somavia of Chile, the then President of the Security Council. Ambassador Somavia, a former NGO leader himself, at that moment, was an important supporter of establishing links between NGOs and the Security Council. As the President of the Security Council, he participated in an NGO public meeting in April 1996. In his opinion, the Security Council needs "closer contact between humanitarian organizations and the Council, and much more information for Council members. Because, finally, the only thing we have on the table from these organizations is what we receive through reports of the SecretaryGeneral. It would be extremely useful to receive reports directly and more often from the organizations themselves. I would advocate closer contact, particularly to learn more of their opinions about these conflicts because they have such a valuable perspective" (Global Policy Forum 1996).

Encouraged by the support of Ambassador Somavia, the NGO Working Group wrote a letter to Paolo Fulci, the incoming president of the Security Council, with a very ambitious proposal. They suggested that the Council President hold a monthly briefing for the NGOs. The permanent members of the Security Council refused the proposal, but the Council affirmed the right of its members, when not serving or speaking as the Council President, to brief NGOs (Paul 2010). Even the fact that the initial proposal of the NGO Working Group was not accepted by the permanent members of the Security Council, the Working Group was the winner in this situation. 
Similarly to Ambassador Somavia of Chile, the next President of the Council, Ambassador Antonio Monteiro of Portugal, expressed enthusiasm for NGOs and persuaded other ambassadors to meet with the Working Group. Representatives of the Working group met with the ambassadors of South Korea, Sweden, Slovenia, etc. Informal NGO contacts with delegations became more common, and Working Group NGO members gained a much higher level of expertise in the Council's operations. The Working Group has established its closest relations with the elected members of the Security Council (Paul 2010).

The late 90s were the new era for the activities of the Working Group. NGO advocacy of security issues has steadily increased. Since the Working Group itself did not take common positions on the most important security issues, members formed separate ad hoc groups to work jointly on advocacy topics. Some of these groups were the NGO Working Group on Iraq, the Children's Watch List, the Working Group on Women, Peace and Security, etc. (Paul 2010). According to theorists, "as criticism of the Council grew, a number of delegations came to see increased Council interaction with NGOs as an essential step toward a more legitimate and effective international political and legal order" (Paul 2004a, 375).

The representatives of the NGO Working Group on the Security Council have met with numerous delegations, ambassadors, presidents of the Security Council, senior UN officers and even the Foreign Ministers of Ireland, Canada, Spain, Austria, Argentina, etc. When it was established in 1995, no one imagined that an NGO body could have a regular informal interaction with the Council members at the highest level. On the one hand, the NGO Working Group is proof that, even in the world of international policy, the unexpected can happen (Paul 2010).

\section{INFORMAL INTERACTION BETWEEN THE SECURITY COUNCIL AND NGOS}

The relationship between the Security Council and NGOs is rated as positive and growing by the legal theorists. The Security Council is "relatively more open, active and effective than we give it credit for" (Trent and Schnurr 2018, 59). Since the end of the Cold War, the Security Council members "have increasingly turned to NGOs as partners and service contractors in emergency and post-emergency situations under the Council's authority" (Hill 2002, 27). All these are important steps forward in improving the reputation of the Security Council and increasing its transparency. But, how much is the Security Council actually open to interaction with NGOs?

The SC-NGO interactions are limited entirely on informal consultation. There are threetypes of informal consultation:

- The "Arria Formula", 
- Regular Meeting Process,

- Bilateral consultations.

Besides these three types of meetings, there are also more indirect forms of interactions between the SC and NGOs, including:

- Naming and shaming,

- The takeover of implementation tasks,

- Lobbying.

For the Security Council, receiving timely information is very important. The most valuable sources of information about developments on the ground in different conflicts were often actors who were not a part of the UN system. The Security Council lacked a working method that would allow it to take advantage of the expertise and information provided by these actors.

In March 1992, while Venezuela held the Security Council presidency, Ambassador Diego Arria was contacted by a Croatian priest who was willing to give his testimony about the violence in Bosnia and Herzegovina to the members of the Council. Since it was impossible to witness the testimony of the priest in an official session of the Security Council, Ambassador Arria invited other members of the Council to meet outside the Council chambers. In the early phase of its establishment, the Arria Formula primarily enabled a member of the Security Council to invite other Security Council members to a meeting held outside the official chambers to be informed by an expert on some important developments on the ground.

In 1996, the use of the Arria Formula was broadened by some elected members of the Security Council to include NGOs and other non-state actors. The permanent members of the Security Council strongly opposed the idea of the broadening of the Arria Formula. After much discussion, in 1999, the Security Council adopted a more flexible meeting arrangement allowing its members to meet with NGOs (Martens 2005, 48). The Arria Formula has been used more regularly since 1999 to provide expertise and testimony on thematic issues taken up by the Council, in particular on humanitarian issues, the Protection of Civilians in Armed Conflict, Children and Armed Conflict and, more recently, on Women, Peace and Security. The Arria Formula meetings are announced by the president of the Security Council at the beginning of each month as part of the regular Council schedule. No Council meetings or consultations are ever scheduled at a time when the Arria Formula meetings take place. The Arria Formula meetings are a significant positive development against the rigid and non-transparent traditions of the Security Council. It allows the Security Council to "open itself in a very limited way to the outside world" (Paul 2003). 
The regular meeting process implies informal briefings between individual members of the Security Council and NGOs, outside the chambers of the Council. During the 90s, the permanent members of the Security Council opposed this form of interaction with NGOs. Despite the opposition of the permanent members, NGOs have met with the Council's ambassadors on a regular basis to exchange information. This kind of interaction has been promoted primarily by the elected members of the Security Council, who have had the most to gain by working with NGOs. Most of the elected members, because of their limited resources, are not able to deal with the workload of the Security Council. They often turn to NGOs in order to obtain information and expertise (Binder 2008, 12).

Bilateral meetings are held between individual NGOs and individual representatives from the Security Council member states. These meetings are also informal and take place outside the chambers of the Security Council. This kind of interaction has been promoted by the elected members of the Security Council as well. Some NGOs have provided expertise to some of the smaller delegations in the Security Council. For the smaller delegations, NGOs expertise is a source of information and ideas necessary to assume their role. With time, even some of the bigger delegations, as well as some of the permanent members of the Security Council, held bilateral meetings with NGOs (Mégret 2020, 45). Bilateral meetings between NGOs and one member of the Security Council have become quite common since the early 2000s. Besides the importance and significant progress of bilateral meetings, theorists are paying attention to the negative side of these meetings. Quite often, bilateral meetings are tightly structured, with some delegations sending junior staff who are not inclined to engage (Hill 2002, 29).

Aside from the regular meeting process, the Arria Formula, and bilateral meetings, NGOs are interacting with the Security Council in less informal ways. These methods are naming and shaming, lobbying and implementing agencies.

Mohamed $(2013,1207)$ defines naming and shaming in international law as "a strategy adopted by an intergovernmental organization, NGO, or government, whereby moral condemnation is directed at a state for its failure to adhere to some shared norm of conduct. This criticism seeks to change that state's behavior by revealing or calling attention to its failure to adhere to a shared norm and perhaps threatening some sanctions to be imposed either by peer governments or by domestic or foreign constituencies". Throughout naming and shaming, NGOs exert pressure on the Security Council to adopt different policies. A good example of naming and shaming is the Global Whiteness campaign against bloody diamonds in Angola, which successfully influenced the Security Council's policymaking. Moral condemnation of the Security Council might be effective in the areas of human rights, humanitarian crises, terrorism, etc. Naming and shaming is a method for putting pressure on the Security Council for its activities or the lack of activities. 
Acting as implementing agencies, NGOs provide the implementation of the Security Council's policy. Their role is important in the field of humanitarian assistance. Acting as implementing agencies, NGOs offer information, provide resources and assist in collective enforcement efforts. Charnovitz (2006, 355) considers resolutions on Yugoslavia (1992) and Sierra Leone (2003) good examples of NGOs' assistance in providing information and resources for the Security Council. In Security Council Resolution 771 regarding the former Yugoslavia, the Security Council states "....and, as appropriate, international humanitarian organizations to collate substantiated information" relating to violations of humanitarian law (UNSC Res. 771). In Security Council Resolution 1470 regarding Sierra Leone, the Security Council calls on "States, international organizations and non-governmental organizations to continue to support the National Recovery Strategy of the Government of Sierra Leone" (UNSC Res. 1470). Having in mind the expanded role of the Security Council in peacekeeping and peace-building, interaction with NGOs may be of particular importance and contribute to its policy.

Finally, lobbying is one of the mechanisms NGOs use to interact with the Security Council. Theorists consider that the most effective lobbying strategy is to combine diplomacy in New York with worldwide public advocacy campaigns. (Paul 2004a, 379) Human rights NGOs often use lobbying. They seek contact with the Security Council representatives in order to convince them to address the issues of concern to them. When lobbying them, they provide data on human rights violations in a particular country for use in official forums (Martens 2005, 49).

\section{NGOS' INFLUENCE ON THE SECURITY COUNCIL'S DECISIONS}

Having in mind that the interaction between NGOs and the Security Council is informal, it is expected that their influence on the decisions of the Security Council will be limited. On the other hand, despite informal interaction, individual NGOs, as well as specialized NGOs formed from the NGO Working Group on the Security Council, have made some important accomplishments in the decisions and politics of the Security Council. It is important to emphasize that specialized working groups did not detract from the main Working Group on the Security Council, but instead strengthened it. They brought their well-developed advocacy concerns into the Working Group's meetings and took advantage of the contacts they made with ambassadors (Paul 2010).

Particularly successful was the new Working Group on Women, Peace and Security. On October 23, 2000, women from Sierra Leone, Tanzania, Guatemala, Somalia and international NGOs addressed the Council in an Arria Formula meeting, revealing the gender-specific conditions and acts that women experience in war. Under the presidency of Namibia, the Security Council held an open session during which more than forty speakers addressed issues of women, peace and 
security (Hill et al. 2003, 1255). The Security Council unanimously passed Resolution 1325 on Women, Peace and Security on October 31, 2000, as a result of the debate. The resolution reaffirms the important role of women in the prevention and resolution of conflicts and peace-building and stresses the importance of their equal participation and full involvement in all efforts for the maintenance and promotion of peace and security, and the need to increase their role in decision-making with regard to conflict prevention (UNSC Res. 1325). It urges all parties to an armed conflict to take special measures to protect women and girls from gender-based violence, particularly rape and other forms of sexual abuse, and all other forms of violence in situations of armed conflict. The resolution provides a number of important operational mandates, with implications for member states and the entities of the United Nations system.

The issue of women's rights and women in war is certainly not a new one, but the Security Council has remained silent on it for a few decades. For the first time, in 2000, the doors "were opened just wide enough for women to squeeze into a Security Council debate for the first time" (Hill et al. 2003, 1265). It sounds unbelievable that Resolution 1325 was the first formal document from the Security Council that required parties in a conflict to prevent violations of women's rights, to support women's participation in peace negotiations and post-conflict reconstruction, and to protect women and girls from wartime sexual violence. The resolution has generated many activities: meetings have occurred between women's organizations and the Security Council; NGOs have produced documents monitoring the progress of its implementation and have held regional consultations in Africa, South Asia, and Europe, developing new information-sharing networks; and the Inter-Agency Taskforce on Women, Peace and Security at the United Nations has coordinated a system-wide implementation strategy. The United Nations Development Fund for Women (UNIFEM) appointed two independent experts to prepare a report on the issue, and the UN Secretary-General has also prepared a study and report (Hill et al. 2003, 1256). Resolution 1325 was "the pivotal link between gender equality and international peace and security" (UN MCPR 2015).

Fifteen years after Resolution 1325, the Security Council adopted unanimously Resolution 2242 with the goal of integrating women's, peace and security concerns across all country-specific situations on its agenda. Resolution 2242 calls upon the Member States to further integrate the women's, peace and security agenda into their strategic plans, such as national action plans and other planning frameworks, including implementation of relevant obligations under international humanitarian law and international human rights law, through broad consultation, including with civil society, in particular women's organizations (UNSC Res. 2242). It encourages the participation of civil society organizations at international and regional peace and security meetings, including donor conferences, to help ensure that gender 
considerations are integrated into the development, prioritization, coordination, and implementation of policies and programs.

NGOs have been influential in children's rights, especially on issues of children in conflict - such as child soldiers, sexual abuse of children by combatants, etc. Bode (2017) describes NGOs' activities regarding children in the armed process as "tactical practices, designed to create space by turning well-timed manipulations of events into opportunities for influence". NGOs' lobbying on this issue resulted in the creation of the United Nations' Special Representative of the SecretaryGeneral on Violence against Children. The Special Representative has made regular field visits to conflict-affected countries and has convinced the Security Council to place the issue of children in armed conflicts on its agenda (Becker 2013,103). The lobbying of NGOs has had an impact on both the General Assembly and the Security Council's deliberations. The UN General Assembly formally adopted the Optional Protocol to the Convention on the Rights of the Child on the involvement of children in armed conflict (OPAC) in 2000. It became legally binding in February 2002. At the same time, the Security Council started adopting a series of resolutions regarding children in armed conflicts. Some of the most important Resolutions of the Security Council on children in armed conflicts are 1261 (1999), 1308 (2000), 1314 (2000), 1379 (2001), 1460 (2003), 1539 (2004), 1612 (2005), etc.

Paul (2004a, 358) states that the influence of NGOs was the strongest in soft policy areas, like Resolution 1325 on Women, Peace and Security and Resolution 1612 on the protection of children affected by armed conflict and child soldiers, etc. NGOs have worked on issues such as Rwanda, Iraq, Sudan, the Balkans, the Great Lakes, disarmament, the Israel/Palestine conflict, etc. In all these cases, the support of the elected members was not enough. They faced the brick wall of the permanent members of the Security Council. The national interests of the permanent members prevailed over the interests of humanity. NGOs were aware of "how Council resolutions were disregarded and undermined by leading members, how powerful members sometimes issued economic threats to win important Council votes (...) and how ambassadors could be chastised or even recalled if they angered mighty opponents" (Paul 2004b). The influence of NGOs on the hard policy areas has been limited.

The Global Witness has succeeded in drawing the international community's attention to the problem of "blood diamonds" by releasing their report "A Rough Trade" in 1998. The report demonstrates how diamonds have helped fund the civil war in Angola. The Security Council consequently adopted Resolution 1295 in April 2000, which consisted mainly of reaffirmations of condemnations and sanctions against UNITA (National Union for the Total Independence of Angola). The Security Council authorized a tightening of sanctions against UNITA and established a panel of experts to investigate violations of Security Council 
resolutions imposing measures against UNITA. If there had been formal mechanisms of cooperation and interaction between NGOs and the Security Council, Global Witness or another NGO could have discovered the facts sooner and put pressure on the Security Council to act on time and on the spot. UNITA has been using conflict diamonds since 1992 to pay for the war. Resolution 1295 was adopted in 2000. During that period, a lot of human lives were lost. If formal mechanisms for cooperation with the Security Council existed, perhaps the Global Witness or some other NGO might prevent further violations of human rights (Bektaş 2017, 21-22).

In all these cases above, the influence of NGOs on decisions of the Security Council was initiated by NGOs. It comes as a result of the Arria Formula, lobbying or some other form of informal interaction.

NGOs have a long tradition of interaction with states and international organizations. When it comes to the Security Council, theorists have mostly positive opinions on the importance of NGOs and their capability to improve the capacity of the Security Council and influence its decisions. Paul (2004b) considers that after more than two decades of NGO action, "the public knows much more about the Council than before, and citizens are in a stronger position to demand accountability for Council action." It also seems that the Security Council is aware of the importance of NGOs for its transparency.

Resolution 2122 on Women, Peace and Security, adopted by the Security Council on 18 October 2003, "recognizes the importance of interactions of civil society” (UNSC Res. 2122). This kind of NGOs' acknowledgment by the Security Council was unimaginable a few decades ago. This resolution was not the last resolution on the acknowledgment of NGOs by the Security Council.

Only a year after passing Resolution 2122, the Security Council expressed even more appreciation for NGOs. In Resolution 2171 on the Maintenance of international peace and security, adopted on 21 August 2014, the Security Council "reaffirms its willingness to strengthen its relationship with civil society, including, as appropriate, though, inter alia, meetings in an informal and flexible manner with civil society, to exchange analyses and perspectives on the issue of the prevention of armed conflict" (UNSC Res. 2171). According to NGO activists, "language on the importance of the role of civil society has become more evident in Security Council thematic and country resolutions (...) The Security Council's increased engagement with civil society comes as a result of civil society efforts (...) to demand entry to Council spaces" (ISHR 2014). 


\section{POSSIBILITIES OF FORMAL INTERACTION BETWEEN NGOS AND THE SECURITY COUNCIL}

Compared with the situation before the Cold War, the relationship between NGOs and the Security Council is progressing. NGOs have used several methods to reach the Security Council. All those methods have been informal and have depended on the agreement of the Security Council members, especially its permanent members. NGOs have shown knowledge, information, will and initiative to access the Security Council. The permanent members of the Security Council have shown resistance and opposition to interaction with NGOs. It looks as if the Security Council is the last bastion to resist formal relationships with NGOs (Bektaş 2017, 28). The elected members of the Security Council have shown much more understanding of the importance of interaction with NGOs. If there was no support and understanding from the elected members, perhaps NGOs would never develop interaction with NGOs. If the President of the Security Council was from the P-5 countries instead of Diego Arria, perhaps the Arria Formula meetings would not have been established.

On the one hand, having in mind the structure, working methods and the lack of transparency of the Security Council, even its informal interaction with NGOs might be marked as progressive. On the other hand, there is no interaction between the Security Council and NGOs on issues that are important to the permanent members. Paul (2004a, 358) emphasizes: "When the P-5 have strong positions, as they often do, NGOs encounter immovable opposition. On sanctions reform, Chechnya, the Middle East, Iraq, and many other important issues, even the most vigorous NGO advocacy runs into a brick wall of P-5 opposition (especially from the United States), as national interest block key NGO concerns."

The Security Council does not have a clear strategy for interaction and cooperation with NGOs. NGOs are non-state actors. At the international level, NGOs are facing some serious challenges. Their nature can be characterized as dual. On the one hand, they are not subjects of international law. From the perspective of international law, there are no legal norms that regulate their legal personality and their rights and obligations under international law. NGOs are using their unregulated and unclear international legal status as an opportunity to undertake various activities in the international arena. In the absence of clear rules and criteria, NGOs are using opportunities to participate in many international activities from which they are not explicitly excluded (Gordanić 2020, 212).

On the other hand, NGOs are very relevant subjects of international relations. Their actions affect and influence states and international organizations. While traditionally, only states have been granted legal personality, it would not be unprecedented for legal personality to extend beyond nations in the international legal sphere. For example, in human rights litigation, multiple international tribunals 
have granted individuals the right to sue on their own behalf (Jedele 2020,138). Today's world is a changing one. Theorists consider that "by 2025, nation-states will no longer be the only, and often not the most important, actors on the world stage and the "international system" will have morphed to accommodate the new reality" (Nijman 2010, 93). The influence of NGOs on the decisions of the Security Council is undeniable, especially having in mind its exclusiveness, closeness and lack of transparency.

The Security Council is not well-prepared for the challenges of the $21^{\text {st }}$ century. It looks like it had lost direction. The UN member states have noticed the encroachment of the Security Council on the competence and jurisdiction of the General Assembly and the other UN organs. The encroachment indicates the tendency of the Security Council to broaden, arbitrarily, the definition of a threat to international peace and security, particularly with respect to thematic debates on social, humanitarian, economic and development issues. On the other hand, the Security Council is unable to deal with issues of international peace and security through a state-based system. The presence of NGOs in this state-based club might be considered as the "tectonic shifts in the international order" (Paul 2004a, 386). In the last few decades, the Security Council has failed a lot of times in its main role - the maintenance of international peace and security. The necessity of formal cooperation between the Security Council and NGOs is a reality of the $21^{\text {st }}$ century. Informal interactions provide limited access to NGOs and do not allow them to operate with efficiency. The Security Council deals with international peace and security. In these kinds of issues, it is a necessity to take appropriate measures in a timely manner. Informal access is not able to provide this request because it depends on the goodwill of the permanent members of the Security Council.

Within the United Nations, NGOs have a long tradition of cooperation with the Economic and Social Council (ECOSOC). Article 71 of the UN Charter regulates the status of NGOs within the UN system. It states: "The Economic and Social Council may make suitable arrangements for consultation with nongovernmental organizations which are concerned with matters within its competence. Such arrangements may be made with international organizations and, where appropriate, with national organizations after consultation with the Member of the United Nations concerned." In the absence of international NGO law as such, Article 71 of the UN Charter "has served de facto as a charter for NGOs" (Charnovitz 2006, 358). So far, more than a thousand NGOs worldwide have acquired consultative status under the provisions of Article 71 of the UN Charter. Consultative agreements are concluded between NGOs and some of the UN specialized agencies.

Consultative status entitles an NGO to attend meetings of the Economic and Social Council and its subsidiary organs, circulate written statements at these 
meetings and make oral statements with the permission of the chair. NGOs with the highest category of consultative status may submit proposals for the agenda of the Economic and Social Council. In addition, consultative status entitles NGOs to gather information, advise member states, obtain support from governments and citizens of member states for UN policy, deliver information regarding UNrelevant operations and provide knowledge and information relevant to the UN.

Could the ECOSOC - NGOs interaction be used as a role model for the formal interaction between NGOs and the Security Council? How can a formal interaction between NGOs and the Security Council be established?

One possible solution is the revision of the UN Charter. The UN Charter was created "as a product of a time that does not exist anymore" (Gordanić 2020, 796). The Charter has shown extraordinary flexibility and applicability in situations that the founders of the United Nations could not predict. Convening a general conference to revise the UN Charter is the only effective way to adapt the structure of the United Nations to the 21st century. One of the most important issues in the UN Charter revision must be the Security Council. Aside from the traditional issues concerning Security Council reform (its membership, the issue of veto power, relations with the General Assembly and other UN bodies), the issue of the Security Council's interaction with NGOs or other non-state actors must be addressed. The UN Charter contains no provision regarding formal cooperation between the Security Council and NGOs. Having in mind the influence of NGOs on the decisions of the Security Council, some form of formal interaction with NGOs is a reality and a necessity of the $21^{\text {st }}$ century. The potential revision of the Charter should consider adding a new article related to the interaction between NGOs and the Security Council. Article 71 of the UN Charter might be used as a role model for the formal relationship between NGOs and the Security Council.

Currently, NGOs are influencing the Security Council and the maintenance of international peace and security indirectly - through their informal consultations on human rights, disarmament, improvement of the position of vulnerable groups in armed conflicts such as women and children, etc. With the establishment of formal interaction, NGOs will be able to have a more direct influence on the maintenance of international peace and security. Also, through formal interaction, NGOs could act as the conscience of the international community. They can turn the attention of the Security Council to conflicts where the actions of the Council are necessary. Having in mind the presence of NGOs on the ground and the insider information they have on certain conflicts, through formal cooperation, the Security Council might be able to improve its knowledge and the quantity of information on conflicts. In that manner, the Security Council will take some actions on time and a lot of human lives in armed conflicts will be saved. 
The other possible solution to the formal relationship between NGOs and the Security Council is granting at least a partial legal personality that would allow NGOs to perform more efficiently. In the case of NGOs, as a category of nonstate actors, there is a discrepancy between the de facto significance and the de jure insignificance (Nijman 2010, 94). NGOs have a long tradition of cooperation with international organizations. International organizations show an open tendency towards cooperation with NGOs and might have multiple benefits: resources in terms of expertise, personnel or funding. If the complexity of problems is high and the resources of international institutions are limited, then the assistance of NGOs in providing additional knowledge and expertise, implementing international organization policies, and monitoring compliance with international agreements are expected to be beneficial to international organizations. NGOs that provide these services might receive access in exchange - they "trade" resources for participation. It might be concluded that the opportunities for an NGO to access an international organization increase with the complexity of the issue and the international organization's demand for resources controlled by the NGO (Binder 2008, 18).

Many authors have instead adopted an open attitude towards recognizing NGOs as international legal subjects. They argue that following a more liberal delimitation of subjects of international law could lead to the conclusion that an entity can be considered a subject of the international legal system if it has rights and/or obligations under that system. NGOs have already gained some degree of de facto international legal personality, at least in terms of law-making (Bakker and Vierruci 2009, 3-4). On the other hand, it is necessary to emphasize that the granting of the international legal personality of NGOs is going to be a very long and perhaps never-ending process. Some authors consider that the "golden age" of NGOs has passed. Also, dilemmas about the legitimacy of NGOs and possible abuses of NGOs for the purposes of powerful states are not favorable to granting legal personality (Vučić 2020,17). States are important sources of income for many international NGOs. The preferences of states' aid agencies can shape NGOs' programs and strategies (Stroup 2020).

\section{CONCLUSION}

NGOs have proven to be important actors in international law and international relations. Their influence on the development of international law is undeniable. Their cooperation with the ECOSOC has existed since the establishment of the UN. Their interaction with the Security Council, on the other hand, has lasted since the Cold War's end. During that period, NGOs have successfully influenced changes in the Security Council's procedures. They have 
established their own regular process of consultation with the Council members and have broadened the Arria Formula.

NGOs have influenced the decisions of the Security Council, but their influence is limited in three aspects. Firstly, their influence was the strongest in soft policy areas. Secondly, NGOs cannot access issues important to the permanent members of the Security Council. Thirdly, the interaction between NGOs and the Security Council is strictly informal. For the issues of international peace and security, it is a necessity to take appropriate measures in a timely manner. Only formal access can meet this request.

Having in mind the structure and the reputation of the Security Council, its informal relations with NGOs have been satisfactory. Transferring relations into a formal mode would increase the transparency of the Security Council and enhance its capabilities. NGOs would be able to provide more resources more efficiently, and the Security Council would be able to address the realities of the international legal order more efficiently. Formal interaction with NGOs might significantly contribute to the quality of the work and decisions of the Security Council. Informally, NGOs have contributed to the maintenance of international peace and security indirectly. Their naming and shaming tactics, the Arria formula meetings and other forms of informal interaction have contributed to saving lives and improving the position of vulnerable groups in international conflicts. NGOs dealing with wars, international conflicts and the positions of vulnerable groups (such as women and children in armed conflicts), have the same goals as the Security Council. That goal is the maintenance of international peace and security. The establishment of formal cooperation with NGOs might benefit the Security Council and improve its working methods and actions in the maintenance of international peace and security.

Of course, the establishment of a formal relationship between NGOs and the Security Council is not going to be an easy-going process. So far, NGOs are not very close to being granted a legal personality. Despite the optimistic attitudes of theorists towards recognizing NGOs as international legal subjects, that is not realistic to happen in the following decade. The revision of the UN Charter might be a possible solution to the establishment of a formal relationship between NGOs and the Security Council. Furthermore, it is unlikely that the Charter will be revised anytime soon. It has been an issue since the establishment of the UN, but it lacks the political will of the member states.

In the context of their relationship with the Security Council, NGOs have been trapped between informal reality and dreams of formal interaction. In the future, NGOs should develop current forms of informal interactions with the Security Council. On the other hand, the Security Council (especially its permanent 
members) should be more open towards NGOs and use NGOs' resources to improve its own working mechanisms and transparency.

\section{REFERENCES}

Bakker, Christine, and Luisa Vierucci. 2009. "Introductions: normative or pragmatic definition of NGOs". In: NGOs in International Law: Efficiency in Flexibility?, edited by: Pierre-Marie Dupuy and Luisa Vierucci, 1-20. Cheltenham and Northampton: Edward Elgar Publishing.

Becker, Jo. 2013. Campaigning for Justice: Human Rights Advocacy in Practice. Stanford: Stanford University Press.

Bektaş, Halil M. 2017. "Analysing relations between the United Nations Security Council and NGOS." TESAM Akademi Dergisi - Turkish Journal of TESAM Academy 4 (2): 11-33.

Binder, Martin. 2008. "The politicization of international security institutions: The UN security council and NGOs". Paper presented at the Annual Conference of the American Political Science Association, Boston, Massachusetts, August $28-31$.

Bode, Ingvald. 2017. "Reflective practices at the Security Council: Children and armed conflict and the three United Nations". European Journal of International Relations 28 (2): 293-318.

Charnovitz, Steve. 2006. "Nongovernmental Organizations and International Law". The American Journal of International Law 10 (2): 348-372.

Dimitrijević, Duško. 2009. Reforma Saveta bezbednosti Ujedinjenih nacija [Reform of the UN Security Council]. Beograd: Institut za međunarodnu politiku i privredu.

Farrall, Jeremy. 2009. "Does the UN Security Council compound the global democratic deficit?". Alberta Law Review 46 (4): 913-932.

Global Policy Forum. 1996. "Ambassador Juan Somavia, Permanent Representative of Chile to the UN; Civil Society and the Security Council - Remarks to the NGO Working Group on the Security Council" April 29. https://archive.globalpolicy.org/component/content/article/198-naturalresources/32910.html

Gordanić, Jelica. 2020. "Položaj nevladinih organizacija u međunarodnom pravu". In: Nedržavni akteri u medunarodnom pravu [Non-state actors in international law], edited by Mihajlo Vučić, 193-222. Beograd: Institut za međunarodnu politiku i privredu.

Hill, Felicity. 2002. "NGO perspectives: NGOs and the Security Council". In: NGOs as Partners: Assessing the Impact, Recognizing the Potential, edited by Kerstin Vignard, 27-31. Geneva: United Nations Institute for Disarmament Research. 
Hill, Felicity, Mikele Aboitiz and Sara Poehlman $\square$ Doumbouya. 2003. "Nongovernmental Organizations' Role in the Buildup and Implementation of Security Council Resolution 1325”. Signs 28 (4): 1255-1269.

[ISHR] International Service for Human Rights. 2014. UN Security Council: Strengthen relationship with civil society and focus on human rights to prevent conflict. August 28. https://www.ishr.ch/news/un-security-councilstrengthen-relationship-civil-society-and-focus-human-rights-prevent

Jedele, Casey. 2020. "Domestic Restrictions on Non-Governmental Organizations and Potential Protections through Legal Personality: Time for a Change?". Chicago Journal of International Law 21 (1): 118-147.

Jovanović, Miloš. 2015. „Ujedinjene nacije i iluzije kolektivne bezbednosti”. In: Sedamdeset godina UN - pogled iz Srbije [Seventy years of the United Nations perspectives from Serbia], edited by Žaklina Novičić and Anđela Đukanović, 5778. Beograd: Institut za međunarodnu politiku i privredu.

Martens, Kerstin. 2003. „Examining the (Non-)Status of NGOs in International Law”. Indiana Journal of Global Legal Studies 10 (2): 1-25.

Martens, Kerstin. 2005. NGOs and the United Nations- Institutialization, Professionalization and Adaptation. New York: Palgrave Macmillan.

Mégret, Frédéric. 2020. “The Security Council”. In: The United Nations and Human Rights, edited by Frédéric and Philip Alston, 39-98. Oxford: Oxford University Press.

Mohamed, Saira. 2013. "Shame in the Security Council". Washington University Law Review 90 (4): 1191-1254.

Nijman, Janne E. 2010. "Non-state actors and the international rule of law: revisiting the 'realist theory' of international legal personality". In: Non-state actor dynamics in international law: from law-takers to law-makers, edited by Math Noortmann and Cedric Ryngaert, 91-124. London and New York: Routledge.

Paul, James. 2003. "The Arria Formula”, Global Policy Forum, October 2003. https://archive.globalpolicy.org/security/mtgsetc/arria.htm

Paul, James. 2004a. "Working with Nongovernmental agencies". In: The UN Security Council-From the Cold War to the 21:t century, edited by David M. Malone, 373389. London: Lynne Rienner Publishers.

Paul, James. 2004b. "NGOs and the Security Council", Global Policy Forum. https://archive.globalpolicy.org/security-council/ngo-working-group-on-thesecurity-council/40406-ngos-and-the-security-council.html\#paradoxes

Paul, James. 2010. "A short history of the NGO Working Group", Global Policy Forum, September 2010. https://archive.globalpolicy.org/ngo-working-groupon-the-security-council-4-24/40407.html 
Rath, Saroj Kumar. 2006. "India and Reform in the Security Council”. In: Reform of the United Nations, edited by K. R. Gupta, 47-63. New Delhi: Atlantic Publishers.

Stroup, Sarah. 2020. "NGOs and States in Global Politics: A Brief Review", EInternational Relations, August 3. https://www.e-ir.info/pdf/86695

Tarlock, A. Dan. 1992. „The Role of Non-Governmental Organizations in the Development of International Environmental Law". Chicago-Kent Law Review 68 (1): 61-76.

Trent, Jonh, and Laura Schnurr. 2018. A United Nations Renaissance: What the UN is, and what it could be. Opladen, Berlin, Toronto: Barbara Budrich Publishers.

[UN MCPR] United Nations Meeting Coverage and Press Releases. 2015. Security Council Unanimously Adopts Resolution 2242 (2015) to Improve Implementation of Landmark Text on Women, Peace, Security Agenda. October 13. https://www.un.org/press/en/2015/sc12076.doc.htm

[UNSC] UN Security Council. Resolution 771, On violations of humanitarian law in the territory of the former Yugoslavia and in Bosnia and Herzegovina, S/RES/771. August 13, 1992. https://digitallibrary.un.org/record/148182

[UNSC] UN Security Council. Resolution 1325, Women, peace and security, S/RES/1325. October 31, 2000. https://undocs.org/S/RES/1325(2000)

[UNSC] UN Security Council. Resolution 1470, On extension of the mandate of the UN Mission in Sierra Leone (UNAMSIL), S/RES/1470. March 28, 2003. file:///C:/Users/Acer/Downloads/S_RES_1470(2003)-EN.pdf

[UNSC] UN Security Council. Resolution 2122, On women, peace and security, S/RES/2122. October 18, 2003. http://unscr.com/en/resolutions/doc/2122

[UNSC] UN Security Council. Resolution 2171, Maintenance of international peace and security- Conflict Prevention, S/RES/2171. August 21, 2004. https://www.un.org/en/ga/search/view_doc.asp?symbol=S/RES/2171\%20( 2014)

[UNSC] UN Security Council. Resolution 2242, Women, peace and security, S/RES/2242. October 13, 2015. http://www.securitycouncilreport.org/ atf/cf/\%7B65BFCF9B-6D27-4E9C-8CD3-CF6E4FF96FF9\%7D/s_res_ 2242.pdf

Vučić, Mihajlo. 2020. „Uvodna razmatranja“. In: Nedř̌avni akteri u međunarodnom pravu [Non-state actors in international law], edited by Mihajlo Vučić, 7-32. Beograd: Institut za međunarodnu politiku i privredu. 


\section{NEVLADINE ORGANIZACIJE I SAVET BEZBEDNOSTI UJEDINJENIH NACIJA: IZMEĐU NEFORMALNE REALNOSTI I MOGUĆNOSTI FORMALNE INTERAKCIJE}

Apstrakt. Nakon okončanja Hladnog rata, nevladine organizacije (NVO) pokazale su inicijativu za interakcijom sa Savetom bezbednosti Ujedinjenih nacija. Od tada je došlo do uspostavljanja nekoliko vrsta neformalnih konsultacija između njih i Saveta bezbednosti. Putem neformalnih konsultacija, NVO su uticale na odluke Saveta bezbednosti iz domena soft politike. U oblastima međunarodnog mira $i$ bezbednosti neophodno je na vreme sprovoditi aktivnosti. Mehanizmi neformalnih pristupa ne ispunjavaju ovaj zahtev zato što prvenstveno zavise od dobre volje stalnih članica Saveta bezbednosti. Autor ispituje mogućnosti za uspostavljanje formalne interakcije izmedu Saveta bezbednosti i NVO. Kao potencijalna rešenja formalne interakcije autor smatra reviziju Povelje UN ili mogućnost da NVO steknu međunarodnopravni subjektivitet. Dok se bar jedna od ovih mogućnosti ne ostvari, autor smatra da je neophodno da Savet bezbednosti, a posebno njegovi stalni članovi, budu otvoreniji prema NVO i da koriste resurse nevladinih organizacija kako bi poboljšali sopstvenu reputaciju i transparentnost.

Ključne rečr: nevladine organizacije (NVO), Savet bezbednosti, revizija Povelje UN, međunarodnopravni subjektivitet, neformalne konsultacije, transparentnost, formalna interakcija, stalne članice Saveta bezbednosti.

Received: 31.05.2021

Accepted: 14.07.2021 